\title{
CLEAN UP OF ACIDIC LEACHATES USING FLY ASH BARRIERS: LABORATORY COLUMN STUDIES
}

\section{K. KOMNITSAS ${ }^{1, *}$ \\ G. BARTZAS 2 \\ I. PASPALIARIS ${ }^{2}$}

\author{
${ }^{1}$ Technical University of Crete, \\ Department of Mineral Resources Engineering, \\ 73100 Chania, Greece \\ ${ }^{2}$ National Technical University of Athens, \\ School of Mining and Metallurgical Engineering, \\ Laboratory of Metallurgy, \\ Zografos Campus, 157 80, Athens, Greece
}

*to whom all correspondence should be addressed: e-mail: komni@mred.tuc.gr

\begin{abstract}
Laboratory column tests were conducted to study the efficiency of lignite fly ash barriers in removing heavy metal ions, such as $\mathrm{Fe}, \mathrm{Zn}, \mathrm{Mn}, \mathrm{Ni}, \mathrm{Cd}, \mathrm{Co}, \mathrm{Al}$ and $\mathrm{Cu}$, present in high concentrations in acidic leachates produced in mining and waste disposal sites. The experimental configuration comprised two $40 \mathrm{~cm}$ long plexiglas continuous flow columns installed in series. An upward flow of synthetic acidic solutions spiked with high concentrations of contaminants was maintained in order to simulate field flow rates and residence times. Sampling ports fitted along the column walls allowed sampling and provided information on geochemical mechanisms within the barrier and contaminant degradation rates in the presence of the reactive material.

The geochemical speciation/mass transfer computer code PHREEQC and the MINTEQ database were used for geochemical modeling of the process.

The experimental results underline the potential of lignite fly ash permeable reactive barriers to remove almost completely, over a long period, high loads of inorganic contaminants from very acidic leachates. The main mechanisms involved in contaminants removal are adsorption at the surface of fly ash and the produced hydrous iron oxides, precipitation and co-precipitation. The toxicity of the reactive material at the end of the treatment period, regarding all heavy metals studied, is limited.
\end{abstract}

KEYWORDS: permeable reactive barriers, fly ash, geochemical modeling.

\section{INTRODUCTION}

Acid mine drainage (AMD) is caused by the oxidation of residual sulphide minerals in the vadose zone of mine tailings and waste rock. The generated effluents are usually extremely acidic and contain elevated concentrations of sulfates, fer- rous iron and dissolved hazardous trace elements. Although buffering of the $\mathrm{pH}$ to near neutral conditions may occur in groundwater, oxidation of $\mathrm{Fe}(\mathrm{II})$ to $\mathrm{Fe}(\mathrm{III})$ takes place when AMD is discharged to receiving surface waters. This generates additional acidity, causes mainly the precipi- 
tation of ferric oxy-hydroxides and has adverse impacts on aquatic ecosystems by lowering the $\mathrm{pH}$ and enhancing mobility of hazardous trace elements (Komnitsas et al., 1995).

Permeable reactive barriers (PRBs) are an emerging technology used for the remediation of acidic leachates and contaminated groundwater. They are defined as "an emplacement of reactive materials in the subsurface designed to intercept a contaminant plume, provide a preferential flow path through the reactive media and transform the contaminant(s) into environmentally acceptable forms to attain remediation concentration goals at points of compliance" (US EPA, 1997). Currently, two basic designs are being used in full scale applications: (1) the funnel and gate and (2) the continuous trench, while other designs are being investigated. Both configurations require information on contaminant concentration, contaminant degradation rate in the presence of the reactive subsurface and groundwater flow rate through the barrier. Reactive media used for the construction of PRBs should be fully characterized prior to their use so that they have low cost, maintain their reactivity over long periods of time, are compatible with the subsurface environment, do not cause any adverse chemical reactions with the constituents of the contaminated plume and do not deplete serving as source of contaminants themselves (Powell et al., 1998). Furthermore, they should promote geochemical reactions resulting in the removal of the hazardous ions from contaminated plumes in stable forms (Blowes et al., 2000). PRBs are installed along the path of the contaminating plume, therefore they should maintain their permeability as secondary precipitates accumulate and result in the attenuation of inorganic species over long periods varying from years to decades.

PRBs are able to remove multiple contaminants depending on the reactive medium used for their construction (Snow, 1999). Zero-valent iron, limestone, fly ash, phosphate, ferrous salts and other compounds (e.g. $\mathrm{Mg}(\mathrm{OH})_{2}, \mathrm{Mg}(\mathrm{CO})_{3}$, $\mathrm{BaCl}_{2}, \mathrm{CaCl}_{2}$ ) are some of the most common reagents that raise $\mathrm{pH}$ to alkaline values and cause the precipitation of heavy metals as stable phases (Morrison, 1998; Ott, 1998). Zero-valent iron has been proven very efficient in reducing chlorinated organic solvents such as trichloroethylene (TCE) while limestone can be used for the clean up of AMD and the subsequent prevention of groundwater contamination.

Research efforts on fly ash barriers to date have focused on the study of mechanisms involved in contaminant uptake. The most important characteristics of fly ash are the calcium content that provides alkalinity in the system raising $\mathrm{pH}$ to strongly alkaline values $(\sim 12)$ and the $\left\{\mathrm{SiO}_{2}+\mathrm{Al}_{2} \mathrm{O}_{3}+\mathrm{Fe}_{2} \mathrm{O}_{3}\right\}$ content. Alkali Fly Ash Permeable Reactive Barriers (AFA-PRBs), constructed from fly ash that otherwise would have been disposed of or landfilled are an emerging and innovative technology that can be effective in removing heavy metals from acidic leachates or contaminated groundwater in an economically feasible manner.

The removal of heavy metals from effluents and wastewaters by adsorption and precipitation on fly ash has been studied by a number of researchers. Bayat (2000, a and b), examined the effectiveness of fly ash for the removal of $\mathrm{Ni}, \mathrm{Cu}$, Zn, Cr and Cd while Mavros et al. (1993) used two different types of fly ash (from the coal fields of Kardia and Megalopolis in Greece) to remove $\mathrm{Ni}$ from wastewater. Weng and Huang (1994) pointed out that fly ash can be used as an effective adsorbent for $\mathrm{Zn}$ and $\mathrm{Cd}$ to clean up dilute industrial wastewaters. Héquet et al. (2001) studied the removal of $\mathrm{Cu}, \mathrm{Zn}$ and $\mathrm{Pb}$ by fly ash and lime mixtures underlining that the most important parameters are fly ash properties, leachates $\mathrm{pH}$, concentration of contaminants and fly ash/lime ratio. The properties of fly ash, which is in many countries a readily available and cheaper reactive material compared to zero-valent iron or activated carbon and the quality of the leachates, in terms of load and toxicity, define the efficiency of fly ash PRBs (Gavaskar, 1999). Another key issue is the residence time of leachates or the contaminated groundwater; this can be determined by taking into account the permeability of the selected media, the reaction rates or half-lives and the initial concentration of the contaminants. It has to be mentioned that after a long treatment period the reactive surface will be coated with metal hydroxides and other precipitates resulting in partial or total loss of porosity and hydraulic conductivity (NATO/CCMS Report, 2002). These disadvantages though can be overcome by careful design and control during construction and operation. 
In the present work, column experiments have been carried out to study the efficiency of lignite fly ash barriers for the removal of inorganic contaminants and the subsequent clean up of extremely acidic leachates generated at mining and waste disposal sites. Column studies offer the following advantages (Gavaskar et al., 1998):

1. Design parameters are determined under dynamic flow conditions. The concentration of contaminants that changes with the distance traveled within the reactive cell can be monitored by installing sampling ports along the column walls.

2. Contaminant half-lives are generally more reliable than those determined through batch tests.

3. Nonlinear sorption is simulated more precisely.

4. Since in a batch system reaction products formed tend to accumulate, continuous flow through columns may force partial re-solubilization for some of them and subsequent deposition in longer distances; this approach is more realistic in actual field conditions.

\section{MATERIALS AND METHODS Materials and methodology}

Laboratory experiments were carried out in duplicate at room temperature using two $40 \mathrm{~cm}$ long and $5 \mathrm{~cm}$ inner diameter plexiglas columns in series. These dimensions are considered as standard and have been used in many research studies. They offer several advantages regarding maintenance of the desired flow rate, study of contaminants degradation profile and modeling of the process. The reactive media in each column contained $50 \% \mathrm{w} / \mathrm{w}$ of Greek fly ash obtained from Kardia thermal power plant and $50 \%$ w/w of silica sand 20-30 mesh $(0.84-0.60 \mathrm{~mm})$. Fly ash is composed of spherical, amorphous ferro-aluminosilicate minerals and has low permeability, low bulk density and high specific surface area. Due to its higher than $50 \% \mathrm{SiO}_{2}+\mathrm{Al}_{2} \mathrm{O}_{3}+\mathrm{Fe}_{2} \mathrm{O}_{3}$ content $(53 \%)$ it is characterized as Class $\mathrm{C}$ and possesses cementitious and pozzolanic properties (Xenidis et al., 2002). Its grain size distribution, evaluated using a Malvern mastersizer microplus laser apparatus with a capability of tracing particles between 0.05 and 556 microns, was $-500+100$ microns: $22 \%,-100+50$ microns: $20 \%,-50+10$ microns: $33 \%$ and -10 microns: $25 \%$. The fly ash used in this study has an almost identical particle size distribution with the fly ashes produced from Agios Demetrios and Ptolemais, Greece, thermal power plants $(20-23 \%>105$ microns, $16-25 \%<$ 63 microns), but it is finer than the fly ash produced from the Amyntaion - Filotas plant (45\% $>105$ microns, $10 \%<63$ microns) (Arditsoglou et. al., 2004). Mixing of fly ash with silica sand was carried out to minimize potential clogging and cementation problems during the later stages of operation. The mixture was placed in the middle section of the column between a $3 \mathrm{~cm}$ silica sand layer at the bottom and a $5 \mathrm{~cm}$ layer at the top. Each column was packed with the reactive media in such a way as to ensure a homogeneous matrix. The average total porosity was 0.33 (total pore volume was $568 \mathrm{~cm}^{3}$ ), while the average flow rate used to simulate real field conditions was $30 \pm 0.25$ $\mathrm{cm}$ per day. Therefore, the calculated leachates flow rate, based on total pore volume, was $1.15 \pm 0.05$ pore volumes per day and the residence time $0.4 \pm 0.05$ days. The porosity was determined by dividing the total pore volume by the volume of the columns while the total pore volume was determined by weighting the columns dry and fully saturated.

The synthetic aqueous solutions used in this study as simulated severe AMD were prepared by adding appropriate concentrations of the target contaminants in deionized water in $\mathrm{HCl}$-cleaned glassware. Initial ion concentration was $1.5 \mathrm{~g} \mathrm{l}^{-1}$ $\mathrm{Fe}(\mathrm{III}), 100 \mathrm{mg} \mathrm{l}^{-1} \mathrm{Al}(\mathrm{III}), 5 \mathrm{mg} \mathrm{l}^{-1} \mathrm{Co}$ (II), $5 \mathrm{mg} \mathrm{l}^{-1}$ $\mathrm{Ni}(\mathrm{II}), 5 \mathrm{mg} \mathrm{l}^{-1} \mathrm{Cu}(\mathrm{II}), 5 \mathrm{mg} \mathrm{l}^{-1} \mathrm{Mn}$ (II) and $20 \mathrm{mg}$ $\mathrm{l}^{-1} \mathrm{Zn}(\mathrm{II})$. The concentrations used are considerably higher than most of those tested in literature in order to allow in a relatively short experimental period the study of the efficiency of lignite fly ash in removing heavy metal ions, the calculation of the optimum residence time and the design of a PRB system. The analytical grade reagents used were iron sulfate monohydrate, $\mathrm{Fe}_{2}\left(\mathrm{SO}_{4}\right)_{3} \cdot \mathrm{H}_{2} \mathrm{O}$, aluminum sulfate 18-hydrate, $\mathrm{Al}_{2}\left(\mathrm{SO}_{4}\right)_{3} \cdot 18 \mathrm{H}_{2} \mathrm{O}$, cadmium triosulfate octahydrate, $3 \mathrm{CdSO}_{4} \cdot 8 \mathrm{H}_{2} \mathrm{O}$, copper sulfate pentahydrate, $\mathrm{CuSO}_{4} \cdot 5 \mathrm{H}_{2} \mathrm{O}$, manganese sulfate monohydrate, $\mathrm{MnSO}_{4} \cdot \mathrm{H}_{2} \mathrm{O}$, zinc sulfate heptahydrate, $\mathrm{ZnSO}_{4} \cdot 7 \mathrm{H}_{2} \mathrm{O}$, nickel sulphate hexahydrate, $\mathrm{NiSO}_{4} \cdot 6 \mathrm{H}_{2} \mathrm{O}$ and cobalt sulfate heptahydrate, $\mathrm{CoSO}_{4} \cdot 7 \mathrm{H}_{2} \mathrm{O}$. The $\mathrm{pH}$ of this simulated leachate was $\sim 2.2$ while the Eh was $\sim 325 \mathrm{mV}$. An upward flow of the synthetic solution was maintained through the columns using a peristaltic pump Gala/4W in order to simulate 
precisely actual field flow rates. The actual experimental flow rate was monitored daily by collecting timed volumes of solutions.

Sampling ports installed along the column walls, at a distance of $20 \mathrm{~cm}$ (sampling port A) and $60 \mathrm{~cm}$ from the inlet (sampling port B), allowed sampling and analysis of the leachates quality during column operation. Samples were collected from each sampling port using glass syringes to avoid disturbance and analyzed for $\mathrm{pH}$ and redox potential (Eh) immediately after sampling with a $\mathrm{pH} /$ Conductivity meter (Metrohm $691 \mathrm{pH}$ meter). Solutions were filtered through $0.45 \mu \mathrm{m}$ filters (Gelman Science sterile aerodisc) and analyzed for total $\mathrm{Fe}, \mathrm{Zn}, \mathrm{Mn}, \mathrm{Al}, \mathrm{Ni}, \mathrm{Cu}, \mathrm{Co}$ and $\mathrm{Cd}$ using Flame Atomic Absorption Spectrophotometry (Perkin Elmer 2100). Sulfate concentration was measured gravimetrically by adding saturated $\mathrm{BaCl}_{2}$ solution to form $\mathrm{BaSO}_{4}$ precipitate. Concentration profiles were generated periodically for all sampling ports and elements of concern. Solid samples of the reactive material were collected at the end of each experiment and analyzed by X-ray diffraction analysis (XRD) using a Siemens 500X Diffractometer to determine all mineralogical phases formed. Toxicity of the used reactive material was determined by the Toxicity Characteristics Leaching Procedure (TCLP, EPA Method 1311) (US EPA, 1986).

\section{Geochemical Modeling}

Geochemical modeling, using the equilibrium computer code PHREEQC (Parkhurst, 1995) and the MINTEQ database (Allison et al., 1991), was performed to determine the ionic forms present in the aqueous phase and to calculate saturation indices.

PHREEQC is a software developed by the US Geological Survey able to perform aqueous geochemical calculations and modeling including

- Speciation and saturation-index calculations

- Reaction-path and advective-transport calculations, involving specified irreversible reactions, mixing of solutions, mineral and gas equilibria, surface complexation reactions, ion-exchange reactions and

- Inverse modeling to determine sets of mineral and gas mole transfers that account for composition changes in solutions within specified compositional uncertainties.

Input parameters were $\mathrm{Al}, \mathrm{Cd}, \mathrm{Cu}, \mathrm{Fe}$ (III), $\mathrm{Mn}$,
$\mathrm{Ni}, \mathrm{Si}$, and $\mathrm{SO}_{4}^{2-}$ for the simulation of the leachates quality and $\mathrm{Fe}_{2} \mathrm{O}_{3}, \mathrm{Al}_{2} \mathrm{O}_{3}, \mathrm{SiO}_{2}, \mathrm{CaO}$ for the interpretation of the geochemical reactions taking place between lignite fly ash and the contaminants. Co was not taken into account since it that does not exist in the MINTEQ database. Calculations show that $\mathrm{Cu}, \mathrm{Cd}, \mathrm{Mn}, \mathrm{Ni}$ and $\mathrm{Zn}$ are mainly present in the leachates (feed) as free ions; $32-40 \%$ of $\mathrm{Cu}$, $\mathrm{Cd}, \mathrm{Ni}$ and $\mathrm{Zn}$ are present as dissolved $\mathrm{MSO}_{4}(\mathrm{aq})$ species. $\mathrm{Al}$ is present as $\mathrm{AlSO}_{4}^{+}$, while $\mathrm{Fe}$ as $\mathrm{FeSO}_{4}^{+}$. The simulated AMD feed is supersaturated with respect to goethite, hematite, jarosite-H, lepidocrocite, maghemite, cupric and cuprous ferrites.

\section{RESULTS AND DISCUSSION}

The most important experimental data derived from leachate analysis at each sampling port as a function of the number of pore volumes passed through the columns are seen below.

The effluent $\mathrm{pH}$ decreased slowly from 12.86 to 11.02 when 37 pore volumes passed through the columns. The $\mathrm{pH}$ at sampling port A decreased more quickly and after 12 pore volumes reached 2.62 while the decrease of $\mathrm{pH}$ at sampling port $\mathrm{B}$ was actually initiated after 32 pore volumes (Figure 1). This indicates that although the lower parts of the PRB, coated with formed precipitates, lose part of their efficiency to buffer $\mathrm{pH}$, the upper parts retain their reactivity for a long period. Over the same period redox potential was maintained at low values and varied between 200 and $350 \mathrm{mV}$, indicating that poor oxidation conditions prevail within the entire reactive materials profile.

Iron was completely removed from the leachates, as seen from measurements at sampling ports B and $\mathrm{C}$, after 37 pore volumes have passed through the columns. It was again detected at sampling port A after 22 pore volumes but precipitated again before reaching sampling port $\mathrm{B}$ due to reaction with "fresh" lignite fly ash (Figure 2a). Iron precipitation was clearly seen by observing the color changes of the reactive material; the initial light, sandy-brown color before the start of the tests turned to a dark yellowish-orange at the end. XRD analysis of the fly ash at the end of the tests revealed that the main iron precipitates were hematite $\left(\alpha-\mathrm{Fe}_{2} \mathrm{O}_{3}\right)$, goethite $(\alpha-\mathrm{FeOOH})$ and in lesser amounts ferrihydrite $\left(\mathrm{Fe}_{5} \mathrm{HO}_{8} \cdot 4 \mathrm{H}_{2} \mathrm{O}\right)$ or iron hydroxide $\left(\mathrm{Fe}(\mathrm{OH})_{3}\right)$ (Allison et al., 1991 and Baltpurvins et al., 1997). Geochemical modeling indicates that iron precipi- 
tates as goethite, hematite and ferrihydrite when $\mathrm{pH}$ ranges between 9-12, 8-9 and 3-8 respectively. Aluminium shows similar to iron behavior. The final effluent concentration was below detection limit and therefore meets remediation concentration goals, but the concentration at sampling ports B and A after 37 pore volumes was 85.6 and $589.3 \mathrm{mg} \mathrm{l}^{-1}$ respectively (Figure $2 \mathrm{~b}$ ). The high concentration measured at sampling port $\mathrm{A}$ is due to re-solubilization of $\mathrm{Al}$ precipitates when fresh acidic leachate flows through the column; partial dissolution of aluminium from fly ash may be also considered. While most of the precipitates were amorphous and therefore could not be detected by XRD analysis, calculation of saturation indices (SI) indicates that $\mathrm{Al}(\mathrm{OH})_{3}(\mathrm{am})$ can precipitate at $\mathrm{pH}$ values higher than 5 . This conclusion is supported by the $\mathrm{pH}$ values recorded at the upper parts of the experimental configuration; these values were well above 5 at sampling port B after 32

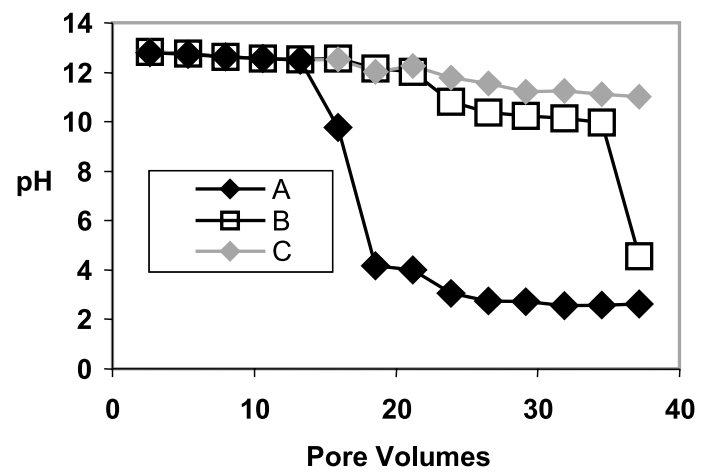

Figure 1. $\mathrm{pH}$ values at sampling ports $\mathrm{A}, \mathrm{B}$ and $\mathrm{C}$ versus pore volumes

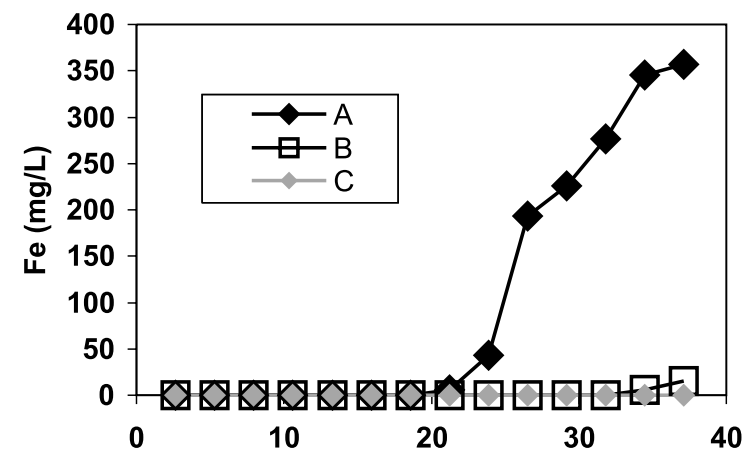

a)

Pore Volumes pore volumes passed through the system.

Copper concentration remains below analytical detection limits at sampling ports $\mathrm{A}, \mathrm{B}$ and $\mathrm{C}$ after 18, 32 and 37 pore volumes have passed (Figure 3a). Geochemical speciation calculations suggest that at $\mathrm{pH}$ values between 5 and 6 copper precipitates as cupric and cuprous ferrite and can be adsorbed on the surface of fly ash, as indicated in previous studies (Manceau et al., 2000).

Zinc concentration in again noticeable in the leachates at sampling ports A and B only after 16 and 32 pore volumes have passed through the columns, whereas it remains below detection limit at sampling port $\mathrm{C}$ at the end of the runs (Figure 3b). $\mathrm{Zn}$ immobilization seems to be combined with sulphate reduction. MINTEQ indicates that $\mathrm{Zn}$ co-precipitates mainly with $\mathrm{Si}$ that is slowly solubilized either from the fly ash or the silica sand at $\mathrm{pH}$ 6-7 and forms willemite $\left(\mathrm{Zn}_{2} \mathrm{SiO}_{4}\right)$ (Héquet et al., 2001, Manceau et al., 2000).

Nickel and cobalt show, as expected, similar behavior and are detected in the leachates at sampling ports A and B only after 16 and 32 pore volumes have passed through the columns (Figures $3 \mathrm{c}, \mathrm{d})$. Concentration at sampling port $\mathrm{C}$ remains for both elements well below detection limit after 37 pore volumes. PHREEQC calculations indicate that nickel precipitates as $\mathrm{Ni}(\mathrm{OH})_{2}$ or coprecipitates as $\mathrm{NiSiO}_{4}$ (Rao et al., 2002).

Cadmium removal trend was similar to copper. Cadmium concentration remained below analytical detection limits for 19, 32 and 37 pore volumes at sampling ports A, B and C respectively (Figure 4a). Modeling and previous studies (Yadawa et al., 1987) indicate that removal of $\mathrm{Cd}$ from leachates is accom-

Figure $2 a, b$. Fe and $\mathrm{Al}$ concentrations at sampling ports $\mathrm{A}, \mathrm{B}$ and $\mathrm{C}$ versus pore volumes (Initial concentrations: $1.5 \mathrm{~g} \mathrm{l}^{-1} \mathrm{Fe}$ and $100 \mathrm{mg} \mathrm{l}^{-1} \mathrm{Al}$ ) 

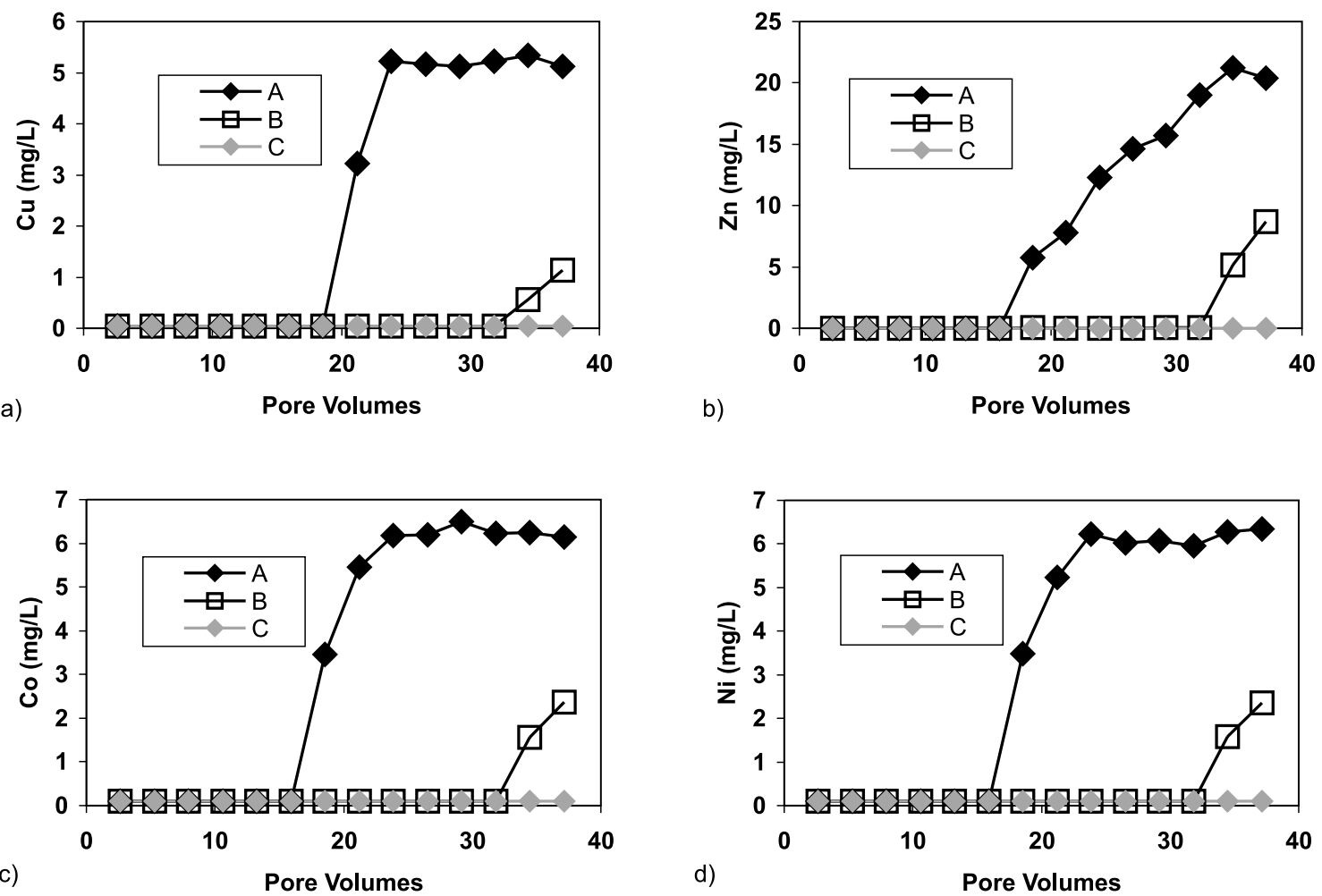

Figure $3 a, b, c, d$. $\mathrm{Cu}, \mathrm{Zn}$, Co and $\mathrm{Ni}$ concentrations at sampling ports $\mathrm{A}, \mathrm{B}$ and $\mathrm{C}$ versus pore volumes (Initial concentration $5 \mathrm{mg} \mathrm{l}^{-1}$ except for zinc $20 \mathrm{mg} \mathrm{l}^{-1}$ )

plished by co-precipitation/adsorption as $\mathrm{CdSiO}_{3}$. Experimental results indicate that the stability of this phase is quite high since its re-solubilization by fresh acidic solutions is limited and does not cause any increased $\mathrm{Cd}$ concentrations at sampling port $\mathrm{A}$ after 37 pore volumes; maximum Cd concentration at this point remains stable at $5 \mathrm{mg} \mathrm{l}^{-1}$.

Manganese is an extremely mobile ion and its removal from leachates is in most cases an extremely difficult task. Study of the Pourbaix diagrams shows that under mild oxidizing conditions manganese is in a +4 valence state and forms an insoluble precipitate, $\mathrm{MnO}_{2}$, while under reducing conditions is converted to the +2 valence state and is present as soluble $\mathrm{Mn}^{2+}$ cation. Manganese reached the initial feed concentration at sampling port $\mathrm{A}$ after 21 pore volumes and exceeded that by three times after 37 pore volumes have passed through the system (Figure $4 \mathrm{~b}$ ). The concentration at sampling port B started to increase after 32 pore volumes, while no Mn was reported at the effluent (port C) after the end of the runs.

Increased Mn concentrations at sampling port A are due to re-dissolution of previously formed unstable precipitates or desorption from the surface of hydrous ion oxides or fly ash by the action of the low $\mathrm{pH}$ fresh AMD or due to leaching of manganese from fly ash (Mn content in fly ash: $310 \mathrm{mg} \mathrm{kg}^{-1}$ ).

From the column experiments carried out it is seen that lignite fly ash PRBs exhibit a noticeable potential for the clean up of acidic leachates containing high loads of various heavy metals, at a rate of $27 \mathrm{~m}^{3}$ per ton of fly ash. By taking into account that this volume includes all hazardous ions studied in this experimental work it is strongly believed that this efficiency will substantially increase in real conditions where less and in lower concentration ions are usually present. Even better results are expected if such barriers are used for groundwater remediation.

The main clean up mechanisms are precipitation and/or surface adsorption. Hydroxides, oxyhydroxides and sulfates are the major compounds formed. Sulfate concentration was decreased from the initial value of $4640 \mathrm{mg} \mathrm{l}^{-1}$ to $2300 \mathrm{mg} \mathrm{l}^{-1}$ 

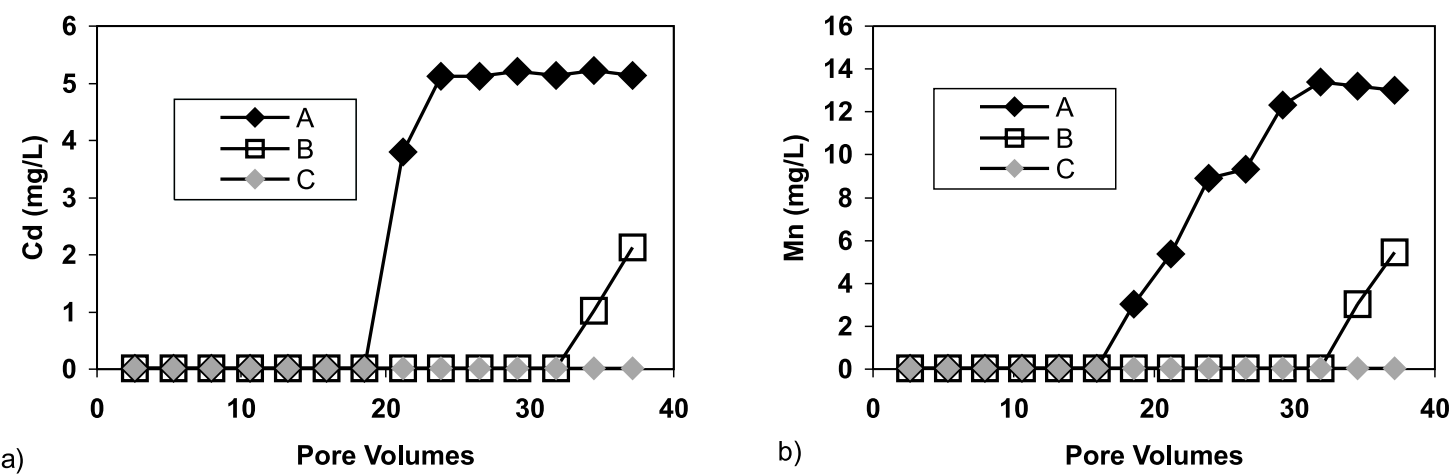

Figure $4 a, b$. Cadmium and manganese concentrations at sampling ports $\mathrm{A}, \mathrm{B}$ and $\mathrm{C}$ versus total pore volumes (Initial concentrations $5 \mathrm{mg} \mathrm{l}^{-1}$ )

at the end of the runs. It has to be underlined though that the formation of hydrated oxide-type sorbents may hinder precipitation of metal hydroxides in a saturated solution as for example happens in suspensions containing silica sorbents that bind copper ions and prevent copper precipitation (Park et al., 1995).

Even though in some cases re-solubilization of some hazardous ions is seen in the first parts of a fly ash PRB due to the flow of "fresh" highly acidic solution, the reactive material has the potential to neutralize this acidity and precipitate most ions very quickly. The $\mathrm{pH}$ dependent sequence of metal hydroxides solubility in the leachates, as determined in this study, $\mathrm{Mn}>\mathrm{Co} \approx \mathrm{Ni}>\mathrm{Cd}>\mathrm{Zn}>\mathrm{Cu}>\mathrm{Al}>\mathrm{Fe}$, is in accordance with that reported in other experimental studies (Stumm and Morgan, 1981).

TCLP tests (US EPA, 1986) performed at the end of the runs show that the toxicity of the resulting precipitates, regarding all hazardous ions in concern, is well below compliance limits, therefore the operation of fly ash barriers is not expected to cause any environmental problems, provided that the local chemical and hydro-geological conditions at the construction site do not alter dramatically with time. Care should be taken though during operation in real field conditions to avoid cementation and clogging by mixing fly ash with inert materials such as silica sand at ratios varying between 1:1 and $1: 3$ and by maintaining saturated conditions within the fly ash barrier. Cementation is caused due to the pozzolanic properties of fly ash and the formation of calcium-silicate hydrates. Similar problems were encountered in the present experimental study towards the end of the runs due to power cuts for a couple of days.

\section{CONCLUSIONS}

Lignite fly ash permeable reactive barriers are efficient in decontaminating extremely acidic leachates, loaded with high concentrations of hazardous heavy metal ions. Experimental column studies show that all contaminants can be completely removed for a long period and provide useful information for the design of PRBs installed in the field for the treatment of such leachates and the prevention of groundwater contamination. The main clean up mechanisms are (i) adsorption at the surface of fly ash particles for $\mathrm{Ni}, \mathrm{Cu}$ and $\mathrm{Cd}$ (ii) precipitation as a separate phase, coating fly ash particles for $\mathrm{Fe}, \mathrm{Al}$ and $\mathrm{Ni}$ and (iii) co-precipitation for $\mathrm{Cu}, \mathrm{Zn}$ and $\mathrm{Cd}$.

Monitoring of the leachates quality along the flow path, by sampling at a number of ports fitted along the column walls, allows the estimation of the optimum residence time required, within the reactive zone, to achieve remediation goals, enabling thus calculation of the required thickness of the permeable reactive barrier. Careful design and control is required though to optimize its performance and avoid operational difficulties under field conditions. In addition, the seasonal anticipated changes of groundwater table should be seriously taken into consideration. Finally, the solubilisation of fly ash elements as well as the re-solubilisation of previously formed unstable precipitates should be also considered in order to optimize the effectiveness of similar PRB systems. It is believed though that the latter factors will not influence to a great extent field applications due to the significantly lower acidity and hazardous load seen in leachates produced in mining and waste disposal areas and in contaminated groundwater. 


\section{ACKNOWLEDGEMENTS}

The authors would like to acknowledge the financial support of the European Commission, in the framework of the Copernicus II ENVIMAN pro- ject, Contract No. ICA2-CT-2000-10010: "Environmental management of hazardous mining wastes and effluents".

\section{REFERENCES}

Allison J.D., Brown D.S. and Novo-Gradac K.J. (1991), MINTEQA2/PRODEFA2: A geochemical assessment model for environmental systems, Version 3.0 User's Manual, Environmental Research Laboratory, Office of Research and Development, U.S. Environmental Protection Agency, EPA/600/3-91/021, Athens, Georgia, 30605, p. 92.

Arditsoglou A., Petaloti Ch., Terzi E., Sofoniou M. and Samara C. (2004), Size distribution of trace elements and polycyclic aromatic hydrocarbons in fly ashes generated in Greek lignite-fired power plants, The Science of The Total Environment, 323, 153-167.

Baltpurvins K.A., Burns R.C., Lawrance G.A. and Stuart A.D. (1997), Effect of $\mathrm{Ca}^{2+}, \mathrm{Mg}^{2+}$, and Anion Type on the Aging of Iron(11l) Hydroxide Precipitates, Environ. Sci. Technol., 31, 1024-1032.

Bayat B. (2002a), Comparative study of adsorption properties of Turkish fly ashes I. The case of nickel(II), copper(II) and zinc(II), Journal of Hazardous Materials, B95, 251-273.

Bayat B. (2002b), Comparative study of adsorption properties of Turkish fly ashes I. The case of chromium (VI) and cadmium (II), Journal of Hazardous Materials, B95, 275-290.

Blowes D.W., Ptacek C.J., Benner S.G., McRae C.W.T. and Puls R.W. (2000), Treatment of dissolved metals and nutrients using permeable reactive barriers, Journal of Contaminant Hydrology, 45, 123-137.

Gavaskar A.R., Gupta N., Sass B., Janosy R. and O'Sullivan D. (1998), Permeable Barriers for Groundwater Remediation: Design, Construction, and Monitoring, Battelle Press, Columbus, $\mathrm{OH}$.

Gavaskar A.R. (1999), Design and Construction Techniques for Permeable Reactive Barriers, Jour. Haz. Mat., 68, 41-71.

Héquet V., Ricou P., Lecuyer I. and Le Cloirec P. (2001), Removal of $\mathrm{Cu}^{2+}$ and $\mathrm{Zn}^{2+}$ in aqueous solutions by sorption onto mixed fly ash, Fuel, 80, 851-856.

Kontopoulos A., Komnitsas K., Xenidis A. and Papassiopi N. (1995), Environmental characterisation of the sulphidic tailings in Lavrion, Minerals Engineering, 8, 1209-1219.

Manceau A., Lanson B., Schlegel M.L., Hargé J.C., Musso M., Eybert-Bérard L., Hazemann J.L., Chateigner D. and Lamble G.M. (2000), Quantitative Zn speciation in smelter-contaminated soils by EXAFS spectroscopy, Am. J. Sci., 300, 289-343.

Mavros P., Zouboulis A.I. and Lazaridis N.K. (1993), Removal of metal ions from wastewaters. The case of nickel, Environ. Technol., 14, 83-91.

Morrison S. (1998), Research and Application of Permeable Reactive Barriers, U.S. Department of Energy, Grand Junction Office, http://www.gwrtac.org/html/tech_status.html.

NATO/CCMS (Committee on the Challenges to Modern Society) (2002), Evaluation of Demonstrated and Emerging Technologies for the Treatment of Contaminated Land and Groundwater (Phase III), EPA 542-R-02-001, Number 250, www.clu-in.org.

Ott N. (1998), Permeable Reactive Barriers for Inorganics, U.S. Environmental Protection Agency Office of Solid Waste and Emergency Response, http://www.clu-in.org.

Park Y.J., Jung K.H. and Park K.K. (1995), Effect of complexing ligands on the adsorption of Cu (II) onto the sillicagel surface, J. Coll. Interface Sci., 172, 447-458.

Parkhurst D.L. (1995), Users guide to PHREEQC: a computer model for speciation, reaction-path, advectivetransport and inverse geochemical calculations, U.S. Geological Survey, Water-Resources Investigations, Report 95-4227.

Powell R.M., Puls R.W., Blowes D.W. and Vogan J.L. (1998), Permeable Reactive Barrier Technologies for Contaminant Remediation, U.S. Environmental Protection Agency, U.S. Office of Research and Development, U.S. Office of Solid Waste and Emergency Response, EPA/600/R-98/125, http://www.epa.gov/ada/pubs/reports.html.

Rao M., Parwate A.V. and Bhole A.G. (2002), Removal of $\mathrm{Cr}^{6+}$ and $\mathrm{Ni}^{2+}$ from aqueous solution using bagasse and fly ash, Waste Management, 22, 821-830.

Snow D. H. (1999), Overview of Permeable Reactive Barriers, Civil Engineering Dept., BYU. 
Stumm W. and Morgan J.J. (1981), Aquatic Chemistry: an Introduction Emphasizing Chemical Equilibria in Natural Waters, Wiley-Interscience, Toronto.

U.S EPA (1986), Test Methods for Evaluating Solid Waste, Volume IC: Laboratory manual physical/chemical methods, SW-846, Office of Solid Waste and Emergency Response, Washington.

US EPA (1997), Permeable reactive subsurface barriers for the interception and remediation of chlorinated hydrocarbon and chromium (VI) plumes in ground water, EPA/600/F-97/008 report, National Risk Management Research Laboratory, Ada, OK 74820.

Weng C.H. and Huang C.P. (1994), Treatment of metal industrial wastewater by fly ash and cement fixation, Journal of Environmental Engineering, 120, 1470-1487.

Xenidis A., Mylona E. and Paspaliaris I. (2002), Potential use of fly ash for the control of acid generation from sulphidic wastes, Waste Management, 22, 631-641.

Yadawa K.P., Tyagi B.S., Panday K.K. and Singh V.N. (1987), Fly ash for the treatment of Cd (II) rich effluents, Environ. Sci. Technol., 8, 225-234. 